\title{
Access to print in low-income and middle-income communities: An ecological study of four neighborhoods
}

\author{
Susan B. Neuman \\ University of Michigan, Ann Arbor, USA \\ Donna Celano \\ Temple University, Philadelphia, Pennsylvania, USA
}

T

here is now a vast body of accumulated evidence on socioeconomic status differences in literacy achievement (Donahue, Voelkl, Campbell, Karweit, Dolan, \& Wasik, 1993; Snow, Burns, \& Griffin, 1998). It is widely known that children reared in middleclass homes with well-educated parents will generally thrive; those who do not are likely to start school behind and stay behind, with patterns of underachievement especially stark for children of diverse cultural, linguistic, and racial backgrounds (Jencks \& Phillips, 1998; Juel, Griffith, \& Gough, 1986; Natriello, McDill, \& Pallas, 1990). Hypotheses for these differences usually reflect some combination of status factors. Low-income households, single parents, and poorly educated mothers essentially add up to large estimations of risk for school failure.

Such inequality in social status, however, has traditionally focused on the attributes of individuals rather than on the social structure of the environment. In contrast, Wilson (1987) argued persuasively that individuallevel analyses (i.e., standard measures of family background) hardly capture the complex dimensions of the social and economic environment; the extent to which communities may differ in outlook and behavior seems due to social isolation and corporate decisions concerning locations of services, resources, and information that the more privileged communities may more easily access. Lareau (1989) in a study of parent involvement, for example, found that despite similar educational goals for their children, parents in lower and middle-class communities differed widely in the skills and resources they had at their disposal for upgrading children's school performance. Social class provided parents with social capital, which they could invest to yield social profits. Differences in individual family status characteristics, therefore, may belie a far more complex network of social class differences (MacLeod, 1995): People absorb from their physical and social universe values and beliefs that guide their actions. And it is the babitus (Bourdieu, 1977), this conglomeration of deeply internalized values, that may continue to reproduce inequality.

Consequently, learning and development cannot be considered apart from the individual's social environment, the ecocultural niche. Fundamental to ecological and sociocultural theories (Rogoff, 1982; 1990), cognition is situated in the social and physical context. Bronfenbrenner's (1979) formalization of this approach was of a set of nested, overlapping, but isomorphic sys- 


\section{Access to print in low-income and middle-income communities: An ecological study of four neighborhoods}

Building on a growing body of ecological research, this study examines access to print in two low-income and two middle-income neighborhood communities in a large industrial city. It documents the availability of print in these communities, focusing on resources considered to be influential in a child's beginning development as a writer and reader. It describes the likelihood that children will find books and other resources, see signs, labels, and logos, public places (spaces) conducive to reading, books in local preschools, school li- braries, and public library branches. Results of the year-long analysis indicated striking differences between neighborhoods of differing income in access to print at all levels of analyses, with middle-income children having a large variety of resources to choose from, while low-income children having to rely on public institutions which provide unequal resources across communities. Such differences in access to print resources may have important implications for children's early literacy development.

\section{El acceso a la escritura en comunidades de ingresos bajos y medios: Un estudio ecológico de cuatro vecindarios}

Fundamentado en un creciente número de investigaciónes ecológicas, este estudio examina el acceso a la escritura en dos comunidades vecinales de bajos ingresos y dos de ingresos medios de una gran ciudad industrial. El estudio documenta la accesibilidad a la escritura en estas comunidades, centrándose en los recursos que se consideran influencias importantes en el desarrollo inicial de los ni os como escritores y lectores. Se describe la posibilidad de que los ni os encuentren libros y otros recursos, ver signos, etiquetas y logos, espacios públicos que conducen a la lectura, libros en los jardines de infantes locales, bibliotecas escolares y bibliotecas públi- cas. Los resultados del análisis llevado a cabo durante un a o indicaron impactantes diferencias entre los vecindarios de diferente nivel de ingresos en cuanto al acceso a la escritura en todos los niveles de análisis. Los ni os de nivel medio disponen de una amplia variedad de recursos para elegir, en tanto que los ni os de bajos ingresos dependen de las instituciones públicas que proporcionan recursos desiguales en las distintas comunidades. Estas diferencias en el acceso a los recursos escritos podría tener importantes implicancias para la alfabetización inicial de los ni os.

\section{Zugang zu Gedrucktem in Gemeinden mit niedrigen und mittleren Einkommensschichten: \\ Eine ökologische Studie von vier Nachbarschaften}

Aufbauend auf einen anwachsenden Grundstock an ökologischer Forschung untersucht diese Studie den Zugang zum Gedruckten in zwei Nachbarschaftsgemeinden mit niedrigen Einkommen und zwei mittleren Einkommens in einer großen Industriestadt. Sie dokumentiert die Verfügbarkeit von Gedrucktem in diesen Gemeinden mit Hinblick auf jene Mittel, die als beeinflussend auf die beginnende Entwicklung eines Kindes hin zum Schreiber und Leser gelten können. Sie beschreibt die Wahrscheinlichkeit, daß Kinder Bücher und andere Hilfsmittel finden werden, Schilder, Etiketten und Logos wahrnehmen, sowie öffentlich vermittelnde Stellen (Ausstellflächen), die dem Lesen dienen, Büchern in örtlichen Vorschulen, Schul- büchereien und öffentlichen Büchereien. Die Ergebnisse der einjährigen Untersuchung ließen auf erstaunliche Unterschiede zwischen den Nachbarschaften mit unterschiedlichen Einkommensstrukturen im Zugang zum Gedruckten auf allen Ebenen der Analyse schließen, wobei Kinder aus mittleren Einkommen über eine große Auswahl an Mitteln verfügen können, während Kinder aus niedrigen Einkommen sich auf öffentliche Einrichtungen verlassen müssen, die nicht vergleichbare Mittel quer durch die Gemeinden anbieten. Solche Differenzen im Zugang zu Druckerzeugnissen können bei Kindern wesentliche Einflüsse auf die frühe Schreib- und Leseentwicklung haben. 


\section{低所得及び中所得のコミュニティーにおける印刷物へのアクセス： 4 つの地域のエコロジカルな研究}

この研究は大きな産業都市の二つの低所得コミュニ ティーと二つの中所得コミュニティーの印刷物への アクセスを調査している。読み書きによる子供の初 期の発展に影響すると思われる情報源を中心に、こ れらのコミュニティーに扔ける印刷物の利用状況が 報告される。子供が本やその他の情報源を見る可能 性が記述され、読書の助けとなる記号、ラベル、ロ ゴ、公的な場所、および、地域の幼稚園、学校の図 書館、図書館の支部の本が分析される。一年に扔よ
ぶ分析の結果、分析対象の全てのレベルで印刷物へ のアクセスに扔いて、著しい地域差が見られること が指摘される。中所得地域の子供たちは選択しうる 情報源を多く持つのに対して、低所得地域の子供た ちは公共施設に依存しており、その公共施設がコミ ユニティーに一様に情報源を与えているわけではな いのだ。印刷物に対するアクセスにおけるそのよう な差異は子供の初期の識字発展に重要な意味を持ち うる。

\section{L'accessiblité différentielle de l'écrit selon le revenu: étude écologique de quatre environnements}

Partant d'un corps croissant de recherches, cette étude examine l'accessiblité de l'écrit pour deux groupes sociaux à bas et à moyens revenus d'une grande ville industrielle. Elle apporte des données sur les écrits accessibles à ces deux groupes, en mettant l'accent sur des ressources dont on peut penser qu'elles ont une influence sur le début du développement de l'enfant en tant que lecteur et scripteur. Elle décrit quelles possibilités ont les enfants de trouver des livres ou d'autres resssources, signes, panneaux, logos, lieux publics (espaces) incitant à la lecture, livres dans les maternelles, bibliothèques d'école, et sections de bibliothèques publiques. Les résultats d'une analyse portant sur une année montrent des différences frappantes d'accessibilité de l'écrit à tous les niveaux de l'analyse entre les environnements aux revenus différents, les enfants de milieu aux revenus moyens ayant la possibilité de faire des choix parmi des ressources nombreuses et variées, tandis que les enfants des milieux à bas revenus doivent s'en remettre à des services publics qui procurent des ressources inégales d'un groupe à l'autre. Ces différences d'accès aux ressources écrites peuvent avoir des conséquences importantes sur l'entrée dans l'écrit des jeunes enfants.

Доступ к печатному слову в сообществах с низкими и средними

доходами: Экомогическое обследование четырех районов

\footnotetext{
На основе многочисленных экологических исследований предпринята попытка изучить доступность печатного слова дия двух сообществ с низкими и двух сообществ со средними доходами в крупном промышленном городе. Основное внимание уделяется источникам, которые оказывают нанбольшее влияние на становцение ребенка в качестве чемовека пишушего и читаюшег. Описана вероятность встречи ребенка с печатными материалами, вывесками, этикетками и Аоготипами, возможность оказаться в способствуюших чтению общсственных местах, пообщаться с книгой в дошкольных учреждениях, школьных библиотеках и
}

филиалах публичных библиотек. Диившиеся год наблюдения демонстрируют значительныс различия между сообществами с разньм уровнем дохода - по всем параметрам проведенного анализа. В то время как дети из семей со средним достатком имеют широқий выбор разнообразных источников, дети из малообеспеченных семей полагаются только на общественные учрехдения, что создает для этих сообществ неравньге возможности. Подобные разАнчия в доступе к печатным материалам могут иметь важные последствия дмя становиения навыков общения детей с языком и книгой 
tems, involving microsystems (i.e., mother and child interactions) to macrosystems (i.e., cultural group or nationstate). Structured by the environment, everyday activities, the "architecture of everyday life" (Gallimore \& Goldenberg, 1993, p. 315), embed opportunities for children to learn and develop through observation and apprenticeship. The environment-its affordances or possibilities and its purposes (Gibson, 1979)—affects what activity settings are likely to be possible, the task demands, the scripts for conduct, the purposes or motives of the participants, and the cultural meaning of the interactions. These activity settings come to shape children's first literacy experiences. It is in these settings that young children will observe and participate in the purposes, styles of interaction, and activities of literacy that are so crucial to their development.

What they learn, of course, will vary according to the activity settings, local practices, and values. For example, in a cross-cultural analysis, Rogoff and her colleagues (Rogoff, Mosier, Mistry, \& Goncu, 1993) found that although there were similarities in the processes of guiding children's participation across cultures, different activity settings supported different communicative functions and different interactions. Similarly, studies of classroom interactions (Neuman, 1995; Neuman \& Roskos, 1997) have demonstrated the influence of settings on children's purposes for literacy and uses of metacognitive strategies, once again indicating the intricate connections between context and cognition.

It is perplexing, then, why much of the literature on differences between middle- and low-income families has given such limited attention to the settings in which literacy begins for young children. The environment has classically served as a backdrop for looking at patterns of interaction, but never as a potential explanatory factor. For example, numerous studies have documented the differences in the frequency of book reading for middle and lower income children (Anderson-Yockel \& Haynes, 1994; Ninio, 1980; Pellegrini, Galda, Jones, \& Perlmutter, 1995; Sigel, 1982; Sonnenschein, Brody, \& Munsterman, 1996). Yet to our knowledge, there have been few attempts to explain the degree to which these environments might afford such opportunities. The prevailing assumption seems to be that books and other literacy-related resources are easily and equally accessible to all children and their families.

This article challenges that assumption. It builds on a growing body of ecological research that examines access to literacy as a potential contributing factor for explaining differences in interactions, behaviors, and ultimately achievement for young children (Entwistle, Alexander, \& Olson, 1997; McQuillan, 1998; Neuman, 1996). Entwistle and her colleagues (1997), for example, have proposed a provocative faucet theory. They suggested that achievement differences are due to seasonal variations in educational opportunity by denying young children the resources they need to grow outside of school, especially in the summer. And focusing specifically on library book access, studies by Krashen and colleagues (Krashen, 1998; Smith, Constantino, \& Krashen, 1996) have substantiated dramatic disparities in three communities, ranging from high to low income.

Such differences in resources may have important consequences for school literacy. Scribner and cole (1981), in their classic study among the Vai people of West Africa, found no relation among the intellectual operations that literacy fosters and general abilities such as abstract thinking. However, they did report critical linkages between well-practiced activities and skill performance in familiar contexts, such as the writing of letters and memorizing of the Qur'an, the Moslem religious text, with skill development closely paralleling their uses in activity settings. Subsequent cross-cultural studies by Lave (1980), examining tailoring in Liberia, and by Greenfield (1974), studying weaving in Zinacanteco, argue for a practice account of situated learning. That is, learning is influenced by the social situation, and the familiarity of the task materials and the cognitive operations associated with them. In fact, some differences across cultures disappear altogether when the materials (i.e., books, props) and cognitive operations, such as recalling stories (Mandler, Scribner, Cole, \& DeForest, 1980), and sorting and classifying tasks (Sinnott, 1975), are equally familiar and accessible to children.

Therefore, if access to print is highly differentiated in our culture, it may result in differential opportunities for certain types of learning and thinking that are related to literacy development. Differences in access could influence the degree of familiarity with book language and the cognitive behaviors associated with reading, helping to explain the substantial educational differences among low- and middle-income children in beginning formal instruction. To date, however, little information is known about the magnitude of differences in access to literacy materials and resources. This study, therefore, examines potential disparities in print environments for thousands of children from four local neighborhoods in a large urban city in the United States. It documents the availability of print in these communities, focusing on resources considered to be influential to a child's beginning development as a reader. It details the likelihood that children will find books and other resources in their neighborhood, see signs, labels, and logos, public places conducive to reading, and books in their local preschools, elementary schools, and public libraries. In so doing, it attempts to build an empirical case for examining the 
supports and constraints that may influence activity settings in children's early literacy development.

There are risks and limitations in this analysis. Most obvious is our working definition of literacy environment. Clearly, the ecocultural structure of a community is more than a matter of material resources (Gallimore \& Goldenberg, 1993); it is the social construction of families and the impact of daily experiences on children's lives. However, material resources, an important part of an ecological setting, have been underexamined as a potential factor for explaining differences in type and quality of everyday experiences. Limited resources can and do serve as powerful constraints on activity (Wilson, 1987). Thus, even when we focus attention on resources, we recognize that people's actions, goals, and circumstances within activity settings are profoundly interconnected.

Related to this limitation is our definition of literacy resources. In this study we focus primarily on resources tied to decontextualized language skills predictive of school literacy success (Snow et al., 1998). Although we acknowledge the accomplishments and the deep valuing of literacy among families (Taylor \& Dorsey-Gaines, 1988), we do not address the specialized funds of knowledge (Moll \& Greenberg, 1990) that are present and that provide a unique information source for children among many households.

More troubling than these limitations, however, might be the tendency for some to view the study as a case for the culture of poverty argument (Peterson, 1991), that is, limited resources for lower class people are the result of a cultural commitment to dysfunctional values. Influential as this thesis has been, it is not only misleading, but also wrong. Among its many critics (Jencks \& Peterson, 1991), Wilson (1997) indicated that behavior is a rational response to economic constraints, a social byproduct of a changed economy whose impact has left inner cities with extraordinarily high levels of unemployment and hopelessness.

And finally, in sharp contrast to the culture of poverty thesis, there will be those who will likely try to make a direct "resources = achievement" linkage, seeking solutions to differences in children's achievement by offering more resources and increasing book collections (Krashen, 1995). Although intuitively appealing, such direct causal connections would be misleading and wrong. Studies (Jencks \& Phillips, 1998; McGill-Franzen \& Allington, 1997) have documented that resources alone are not likely to improve achievement.

To the contrary, this study makes no such claims. Rather, it argues that as a sociocultural phenomenon, literacy develops in settings that provide resources and opportunities for children to become involved with its cultural tools. Differences in these settings are likely to contribute to the considerable variations in patterns of early literacy development. Thus, to understand how literacy begins for a growing diversity of children, we must study the environments in which they come to know and experience literacy in its many forms.

\section{Method}

\section{Setting and sample}

This project is part of a 3-year study, funded by the William Penn Foundation, designed to examine the impact of community institutions on children's early literacy development. The study is centered in Philadelphia, the fifth largest city in the United States (population, 1.5 million). Known as a city of neighborhoods, Philadelphia has become home to a large number of immigrants (Polish, Italian, Irish, Russian, Hispanic, Chinese, and Southeast Asian) and African Americans as a result of the industrialization in the late 19th and early 20th centuries. Like other major cities, many cultural and ethnic communities have developed over the years, some thriving more than others. People in the city live in its neat brick row homes as well as its back alleys and decaying buildings.

Four neighborhoods in the city were selected for analysis, two low income and two middle income. Several criteria were used for selection. Each of the neighborhoods supported a variety of community services. Recreational departments, local public libraries, and organized community associations all served to define them as active and vital communities. Each had its own distinctive character and ethos, allowing us to compare and contrast variations in resources in very different communities. And, unlike other areas, each had a stable population; people grew up and stayed in these communities throughout their lives.

Kensington and Kingsessing are both low-income neighborhoods. Kensington is a dense, multiethnic community consisting of Puerto Rican, Black, Vietnamese, Eastern European, and Caucasian family sections, all of which are highly segregated. Although the community has areas of urban decay, it is lively and dynamic with beautiful urban gardens hidden throughout the area. Kingsessing is a more socially isolated community, contained by physical and natural boundaries. Largely African American, it has many local businesses, shops, and carryout food stores, some of which are well maintained, others in disrepair. Although the signs of poverty are throughout, there is a Rockwellian ethos in the community with children playing double dutch in the streets, walking their dogs, and bike riding around the playgrounds.

In contrast, Roxborough and Chestnut Hill, the two middle-income neighborhoods, look and feel suburban, 
Table 1 Demographics of four neighborhoods

\begin{tabular}{|c|c|c|c|c|c|c|c|}
\hline \multirow{2}{*}{$\frac{\text { Neighborhood }}{\text { Kensington }}$} & \multirow{2}{*}{$\begin{array}{l}\begin{array}{l}\text { Total } \\
\text { population }\end{array} \\
14,786\end{array}$} & \multirow{2}{*}{$\frac{\begin{array}{l}\text { Juvenile } \\
\text { population }\end{array}}{4,890}$} & \multicolumn{2}{|c|}{ \% Ethnicity } & \multirow{2}{*}{$\frac{\% \text { Poverty }}{46}$} & \multicolumn{2}{|c|}{$\%$ Educational attainment } \\
\hline & & & $\begin{array}{l}\text { Caucasian } \\
\text { Hispanic } \\
\text { Black }\end{array}$ & $\begin{array}{r}65 \\
26 \\
6\end{array}$ & & $\begin{array}{l}\text { Below 12th grade } \\
\text { High school graduate } \\
\text { Some college }\end{array}$ & $\begin{array}{r}4 \\
85 \\
11\end{array}$ \\
\hline Kingsessing & 35,436 & 9,686 & $\begin{array}{l}\text { Black } \\
\text { Caucasian } \\
\text { Other }\end{array}$ & $\begin{array}{r}82 \\
10 \\
8\end{array}$ & 90 & $\begin{array}{l}\text { Below 9th grade } \\
\text { Below 12th grade } \\
\text { High school graduate }\end{array}$ & $\begin{array}{r}5 \\
30 \\
65\end{array}$ \\
\hline Roxborough & 36,052 & 6,770 & $\begin{array}{l}\text { Caucasian } \\
\text { Black }\end{array}$ & $\begin{array}{r}95 \\
5\end{array}$ & 0 & $\begin{array}{l}\text { Below 12th grade } \\
\text { High school graduate } \\
\text { College }\end{array}$ & $\begin{array}{r}6 \\
73 \\
21\end{array}$ \\
\hline Chestnut Hill & 10,168 & 1,239 & $\begin{array}{l}\text { Caucasian } \\
\text { Black } \\
\text { Other }\end{array}$ & $\begin{array}{r}73 \\
25 \\
2\end{array}$ & 0 & $\begin{array}{l}\text { Below 12th grade } \\
\text { High school graduate } \\
\text { Some college } \\
\text { Graduate }\end{array}$ & $\begin{array}{l}11 \\
16 \\
47 \\
26\end{array}$ \\
\hline
\end{tabular}

even rustic. Compared to the density of the two low-income neighborhoods, both communities are spread out and closely adjoin several large parks. Roxborough, a blue-collar Irish and Eastern European neighborhood, is becoming increasingly gentrified with stores, restaurants, and clubs throughout its main street. Chestnut Hill, a well-known integrated community (African American and Caucasian), on the other hand, is largely inhabited by older money. In contrast to the natural sense of community that exists in Kensington and Kingsessing, Chestnut Hill seems more programmed, with children rarely seen on the streets except in organized activities. In Table 1, basic demographic information highlights many of the differences between the four neighborhoods. Neighborhood borders were determined by census tracts.

\section{The research design}

Our multicultural research team included a project investigator, a project coordinator, and six applied urban anthropology doctoral students. Together, we devised a research strategy to examine literacy resources and opportunities in each community. This strategy recognized that any one variable, or measure in and of itself, could not explain variations in print access and opportunity. Rather, we hypothesized that each measure operated within a web of relationships, acting simultaneously and in ways that intersected with one another. Initial data collection and analysis were followed by additional data collection and analysis throughout the year.

The research team devised a theory of community influences that might have an impact on children's early literacy development (Connell, Kubisch, Schorr, \& Weiss,
1995). On the basis of accumulated evidence from early literacy research, the theory implies that children learn about literacy through contact, experiences, and observations of written language use in their everyday lives (Goodman, 1986; Neuman \& Roskos, 1997; Teale \& Sulzby, 1989). Children construct an understanding of how print works through their independent explorations of print and signs, interactions around books and other print resources, and participation with others engaged in purposeful literacy activities. Accordingly, community access was operationally defined as (a) the quantity and selection of children's books that parents could conceivably purchase in the neighborhood, (b) the environmental print (signs, labels, and logos) in the business area that children might begin to identify, (c) the public areas where children might observe people reading, (d) the quantity and quality of books in the child-care centers they would most likely attend, (e) the quantity and quality of books in the local elementary school libraries, and (f) the collections in the local public library. Although each of these influences most likely plays some role, together they might play a powerful role in children's development as literacy learners. From this initial formation, we developed analytic techniques to measure these community variables. Six studies, as follows, were conducted throughout the year.

Survey of reading materials. Using the census boundaries, research assistants walked each block throughout a neighborhood, stopping at every store (i.e., bookstore, grocery store, bodega) likely to have reading resources for purchase: newspapers, magazines, children's books, and teen and adult books. Total number of titles, 
descriptions of the types of materials, and age distribution for the materials were placed on a spreadsheet. To the degree possible, we also counted newspaper boxes, honor boxes, and newspaper stands by type of newspapers. For the purposes of this study, information on children's resources was then plotted on maps to provide information on proximity to resources across the neighborhood.

Signage. Since children often begin to define their world through signs and logos, we studied the signage in each neighborhood. Studies (Goodman, 1986; McGee, Lomax, \& Head, 1988) suggest that the quality of signs, their color, shape, and definitional scripts can be an enabler for young children, allowing them to practice what it is like to be a reader before actually being able to read. To examine signage, research assistants defined the local business area in each neighborhood. They recorded the name of each sign, its condition (good/identifiable or poor), and whether or not it provided a logo (e.g., McDonald's arches). This information was placed on a spreadsheet, and total numbers and corresponding percentages (because business areas varied in size) were calculated for each neighborhood. Photographs were also taken in each neighborhood to illustrate types and quality of signs.

Public spaces (places) for reading. Children begin to uncover the mysteries of written language through observations and participation with those more competent in literacy activity (Teale \& Sulzby, 1989; Tharp \& Gallimore, 1988). From these and other demonstrations, they begin to imitate some of the actions associated with reading and writing and become motivated to learn more about it. We reasoned, therefore, that regular, routine, and habitual uses of reading in public might support the view that reading is important, enjoyable, and pervasive in a community.

To examine reading in public places, research assistants (now quite familiar with the community) asked local residents where one might be able to get a cup of coffee and a newspaper, and sit for a spell and relax. Outdoor spaces were eliminated since winter was quickly approaching. Residents identified five places in each community. They included laundromats, bookstores, pizza parlors, bus stops, diners, coffee shops, and fast-food restaurants.

Research assistants observed and documented activity in each place for approximately 2 hours, for a total of 40 hours. Focusing on what was being read, by whom, and for how long, they also examined environmental features of the setting (i.e., lighting, seating) and how they seemed to support or detract from reading activity. Initial discussions among the research team indicated that these features seemed to dramatically influence the numbers of people involved in reading activities. For example, without much lighting in a coffee shop, it would be impossi- ble to read more than a few words without strain. Therefore, our focus turned to an analysis of these features. Each observation was reviewed, and 17 environmental features were identified. Observations were then examined according to these attributes by three members of the research team, who had visited all or most of the settings, and comparisons were made across community through discussion.

Books in child-care centers. Because increasing numbers of children spend most of their day not around their neighborhood, but in child-care centers within the area in which they live (Children's Defense Fund, 1999), our next step was to focus on access to books in childcare centers. Considering that independent access to books is likely to be particularly important for 3- and 4year-old children, we randomly selected two classrooms in six not-for-profit child-care centers in each neighborhood (i.e., 48 classrooms). Rather than attempt to count the number of books available, we used an adaptation of the Environmental Rating Scale (ECERS) (Harms \& Clifford, 1980) to measure the quality of early childhood environments, and include a literacy component from the first author's previous research (Neuman, 1999a). For the purposes of this study, only two areas of the literacy environment were examined. Children's book displays were rated for availability, according to a scale of 1 (no books accessible to children) to 7 (books available in library corner and other interest areas around the room). Quality was rated from 1 (no attractive books displayed) to 7 (variety of genre and a wide range of age-appropriate selections). Two research assistants independently rated availability and quality in five centers to establish reliability. Interrater reliability was .90. Then, the research assistants independently visited classrooms according to the assigned area and rated each classroom environment.

School libraries. We next visited the local school libraries. Many young children were likely to attend prekindergarten and kindergarten in elementary schools and later go on to the middle schools in the neighborhood. We concentrated on public schools, but included several parochial and private ones if they seemed to draw large numbers of children from the local area. Visiting a total of 24 schools, we examined (a) their resources (i.e., number and condition of available books-book count was estimated by multiplying the number of books on a shelf times the number of shelves, and condition was estimated by publication date and condition of the cover on a random selection of books); (b) staffing (i.e., librarian's training and years of work experience); and (c) children's access (i.e., number of days the library was open per week, and whether children could visit independently or needed to go at designated times). Differences in 
quantity and quality of books and book access were then compared across communities.

Public libraries. Our final analysis focused on the public library branches in each neighborhood.

Recognizing that circulation statistics can distort library activity (i.e., inability to pay library fines), we limited our analysis to the size of the collection, average number of books per child and adult in the catchment area, and hours of library service for each branch.

Throughout the year, we held weekly meetings and discussed preliminary and ongoing findings. As much as possible, we viewed these studies as different layers of access to literacy and thus sought to conduct the studies in simultaneous waves. We began each study with an initial protocol, which would then be refined in the first weeks of data collection. Following each study, research assistants would independently summarize their studies in analytic memos. These summaries would help to refine and further define next steps. In doing all this, we attempted to conduct over the course of a year the most thorough and comprehensive analysis to date of community access to literacy for middle- and low-income neighborhoods.

\section{Results}

Results of the data were consistent within each study and triangulated across studies. There were minor differences in access to print between neighborhoods of similar income, but major and striking differences at almost all levels between neighborhoods of different income. These data indicate that children from middle-income neighborhoods were likely to be deluged with a wide variety of reading materials. However, children from poor neighborhoods would have to aggressively and persistently seek them out.

\section{Survey of print resources}

Table 2 describes the number of stores in each area that carried children's books and magazines. In Chestnut Hill and Roxborough, 11 and 13 places respectively sold print materials for children. There were seven bookstores with special sections for children in Chestnut Hill and three bookstores, with a large children's selection in one, in Roxborough. In contrast, Kingsessing and Kensington, with a far greater density of children, had 4 places in each community that carried children's print materials. No bookstores were found in either neighborhood.

As shown in Table 2, drugstores were the most common source of print materials for children. Young adult materials, defined as chapter books, or magazines more suitable to middle-grade children in all areas were scarce. Apart from the bookstores and a couple of convenience stores in the middle-income areas, these materials were largely absent in any business establishment.

Looking more closely in each area, Tables $3 \mathrm{a}$ through $3 \mathrm{~d}$ describe an even more disturbing picture and equation. To provide some evidence of choice (not quality), we counted the number of different children's titles in each store. Detailing the type of store, number of children's titles, and general type of reading material (e.g., magazines, books, comics), massive differences were reported in print access across community-not only in number, but in type of materials available. Children in Chestnut Hill, for example, had access to literally thou-

Table 2 Number of places selling children's reading resources

\begin{tabular}{|c|c|c|c|c|}
\hline Stores & Kensington & Kingsessing & Roxborough & Chestnut Hill \\
\hline \multicolumn{5}{|l|}{ Children's resources } \\
\hline Bookstores & 0 & 0 & 1 & 3 \\
\hline Drugstores & 2 & 1 & 5 & 2 \\
\hline Grocery stores & 0 & 1 & 3 & 1 \\
\hline Bargain stores & 1 & 1 & 2 & 0 \\
\hline Corner stores & 1 & 0 & 0 & 0 \\
\hline Other stores & 0 & 1 & 1 & 1 \\
\hline Children's stores & 0 & 0 & 1 & 4 \\
\hline Total & 4 & 4 & 13 & 11 \\
\hline \multicolumn{5}{|l|}{ Young adult } \\
\hline Bookstores & 0 & 0 & 1 & 1 \\
\hline Drugstores & 0 & 0 & 1 & 0 \\
\hline Grocery stores & 0 & 0 & 0 & 0 \\
\hline Bargain stores & 0 & 0 & 0 & 0 \\
\hline Corner stores & 0 & 0 & 0 & 0 \\
\hline Other stores & 0 & 0 & 1 & 0 \\
\hline Total & 0 & 0 & 3 & 1 \\
\hline
\end{tabular}


Table 3a Reading resources in Kensington

\begin{tabular}{llcll}
\hline \hline Store name & Type & Children's titles & Young adult titles & Type \\
\hline Rite Aid & Drugstore & 112 & 0 & Book/magazines (picture, puzzle, comics, activity) \\
Rite Aid & Drugstore & 142 & 0 & Book/magazines (picture, puzzle, comics, activity) \\
Chico's Cut Rate & Bargain store & 95 & 0 & Magazines (comics) \\
Maria's Candy & Corner store & 9 & 0 & Magazines (comics, puzzles) \\
Total & & 358 & 0 & \\
\hline
\end{tabular}

Table 3b Reading resources in Kingsessing

\begin{tabular}{llcll}
\hline \hline Store name & Type & Children's titles & Young adult titles & Type \\
\hline Pharmacy & Drugstore & 15 & 0 & Magazines \\
Thriftway & Grocery store & 5 & 0 & Magazines \\
Dollar Store & Bargain store & 30 & 0 & Books (coloring) \\
Newstand & Other & 5 & 0 & Magazines \\
Total & & 55 & 0 & \\
\hline
\end{tabular}

Table 3c Reading resources in Roxborough

\begin{tabular}{|c|c|c|c|c|}
\hline Store name & Type & Children's titles & Young adult titles & Type \\
\hline Encore Books & Bookstore & 1,000 & 500 & Books \\
\hline CVS & Drugstore & 18 & 0 & Books \\
\hline Rite Aid & Drugstore & 34 & 0 & Books/magazines \\
\hline Eckerd & Drugstore & 69 & 0 & Books \\
\hline Eckerd & Drugstore & 55 & 0 & Books/magazines (coloring/activity, easy crossword) \\
\hline CVS & Drugstore & 27 & 30 & $\begin{array}{l}\text { Books (picture, coloring/activity, popular } \\
\text { teen fiction) }\end{array}$ \\
\hline Superfresh & Grocery store & 20 & 0 & Books (Golden books, coloring/activity) \\
\hline Superfresh & Grocery store & 27 & 0 & $\begin{array}{l}\text { Books/magazines (Disney, Read \& Listen, } \\
\text { coloring/activity, comics) }\end{array}$ \\
\hline Acme & Grocery store & 14 & 0 & Books (bargain) \\
\hline Dollar Store & Bargain store & 35 & 0 & Books (toddler, picture, coloring) \\
\hline Dollar Store & Bargain store & 31 & 0 & Books/magazines (picture, activity, Disney, comics) \\
\hline $\begin{array}{r}\text { World Wide } \\
\text { Aquarium }\end{array}$ & Other store & 30 & 0 & Books ("family style" books about pets) \\
\hline $\begin{array}{l}\text { Family Toy } \\
\text { Warehouse }\end{array}$ & Children's store & 237 & 30 & $\begin{array}{l}\text { Books (toddler, picture, workbooks, } \\
\text { Golden books, coloring/activity) }\end{array}$ \\
\hline Total & & 1597 & 560 & \\
\hline
\end{tabular}


Table 3d Reading resources in Chestnut Hill

\begin{tabular}{|c|c|c|c|c|}
\hline Store name & Type & Children's titles & Young adult titles & Type \\
\hline Borders & Bookstore & 14,000 & Unspecified & Books \\
\hline $\begin{array}{l}\text { Christian Literature } \\
\text { Crusade }\end{array}$ & Bookstore & 640 & 0 & Books (toddler, picture, coloring) \\
\hline $\begin{array}{l}\text { Philadelphia } \\
\text { Print Shop }\end{array}$ & Bookstore & 1 & 0 & Books (coloring) \\
\hline CVS & Drugstore & 7 & 0 & Books (coloring) \\
\hline Eckerd & Drugstore & 34 & 0 & Books (toddler, workbooks, coloring/activity) \\
\hline Superfresh & Grocery store & 6 & 0 & Books/magazines \\
\hline Chris's Store & Children's store & 10 & 0 & Unspecified \\
\hline Benders & Children's store & 1,000 & 0 & Unspecified \\
\hline O'Doodles & Children's store & 115 & 0 & $\begin{array}{l}\text { Books (toddler, picture, educational coloring, } \\
\text { family style art) }\end{array}$ \\
\hline Mes Enfants & Toy store & 120 & 0 & Books (toddler, picture) \\
\hline $\begin{array}{l}\text { Performing } \\
\text { Arts Store }\end{array}$ & Other & 520 & 0 & $\begin{array}{l}\text { Books (scripts, scores, toddler, stories, } \\
\text { multicultural, dance, biography) }\end{array}$ \\
\hline Total & & 16,453 & & \\
\hline
\end{tabular}

Table 4 Number and condition of signs in four neighborhoods

\begin{tabular}{lcccc}
\hline \hline Neighborhood & Business signs & Logos & \% Good condition & \% Poor condition \\
\hline Kensington & 209 & 42 & 66 & 34 \\
Kingsessing & 76 & 16 & 26 & 74 \\
Roxborough & 168 & 44 & 96 & 4 \\
Chestnut Hill & 77 & 28 & 99 & 1 \\
\hline
\end{tabular}

sands of book, magazine, and comic-book titles.

Roxborough children, though with access to far fewer, still had substantial numbers of book titles to choose from, whereas children in Kensington had only hundreds and in Kingsessing even fewer. No young adult titles were available in either of the two lower income neighborhoods.

These data indicate that the equation was dramatically skewed in favor of children from middle-income communities. There were about 13 titles for every 1 child in Chestnut Hill, and 1 book title for about every 3 children in Roxborough. Compare this situation with the low-income communities: There was 1 title for about every 20 children in Kensington and 1, all of which were coloring book titles, for about every 300 children in Kingsessing.

Consequently, even though living in the same city, children's access to print resources was widely differential. In these low-income neighborhoods, children would find it difficult, if not impossible, to purchase a book of any quality in local stores; in the middle-income neighborhoods, children would find it hard to escape them.
Such differential access might account for differential print exposure as recorded in research by Stanovich and his colleagues (Stanovich \& Cunningham, 1993; Stanovich \& West, 1989).

\section{Signage}

Children extract meaning from their environment through signs. Although they are not actually reading at an early age (Stahl \& Murray, 1993), visually distinctive environmental print (product labels, restaurant signs, street signs) help children to understand their environment, become involved in it, and locate particular services and activities for future occasions. Children often act as if they are readers long before formal reading instruction, by reading signs, particularly logos (e.g., Pizza Hut) conveying their beginning understanding that print has meaning. Signs also reflect how print is used in community environments.

Table 4 describes the number and condition of signs in the center of each neighborhood. Signs were 


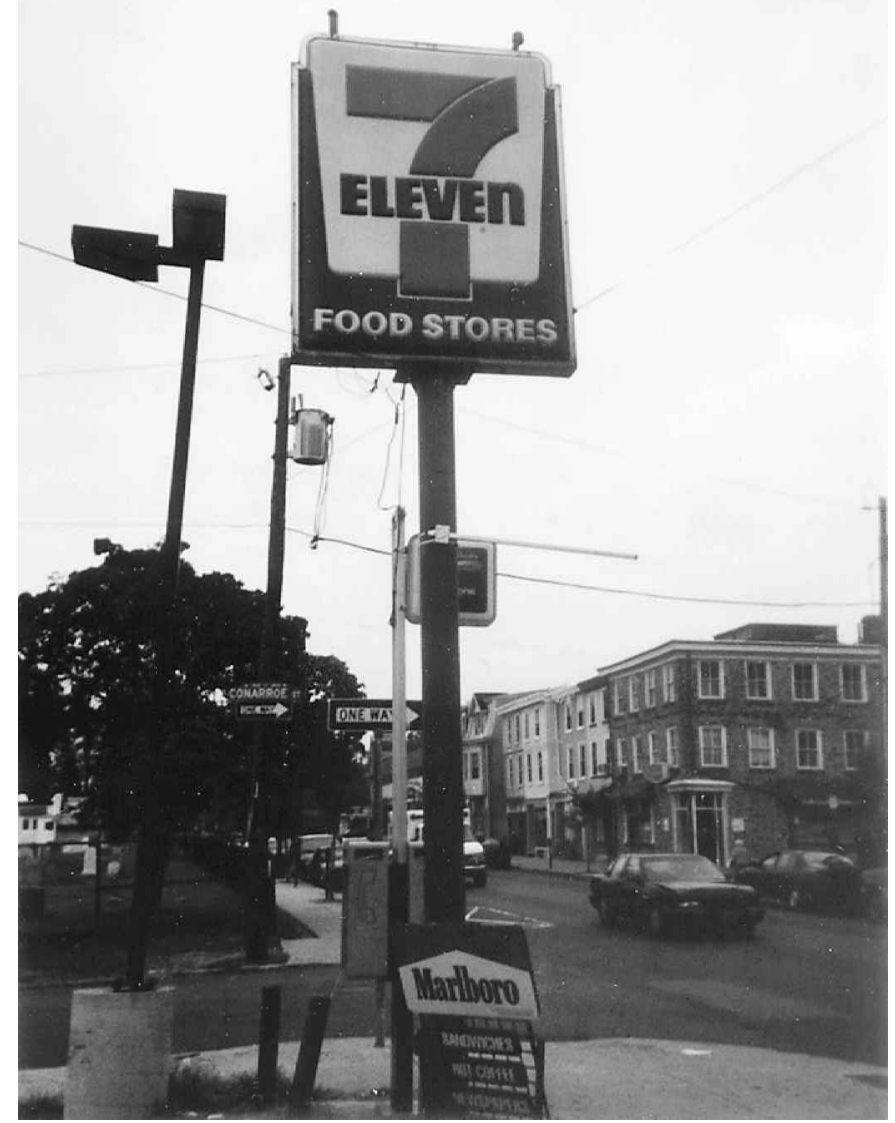

Example of logographic signs in Chestnut Hill. Photo by William McKinney.

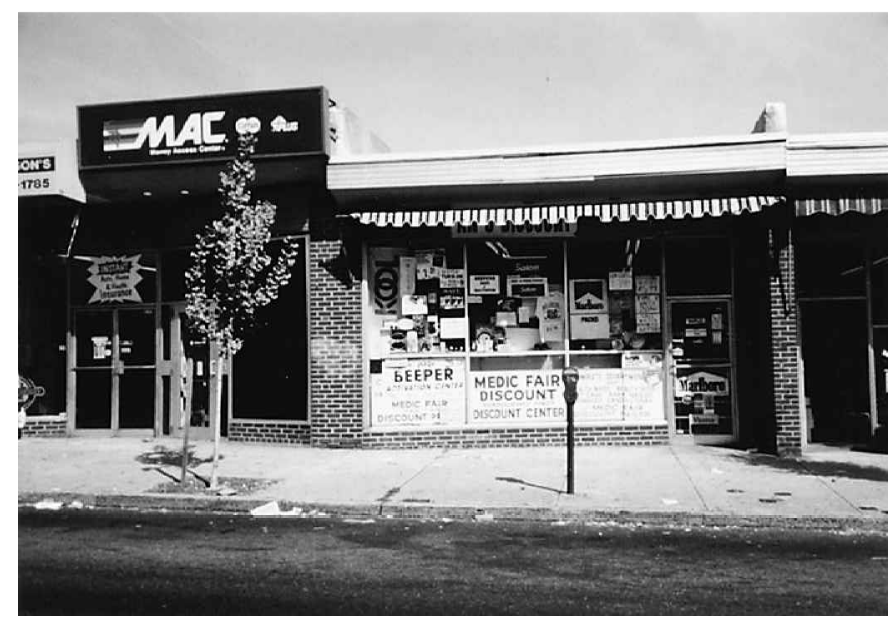

Examples of signs in Chestnut Hill. Photo by William McKinney.

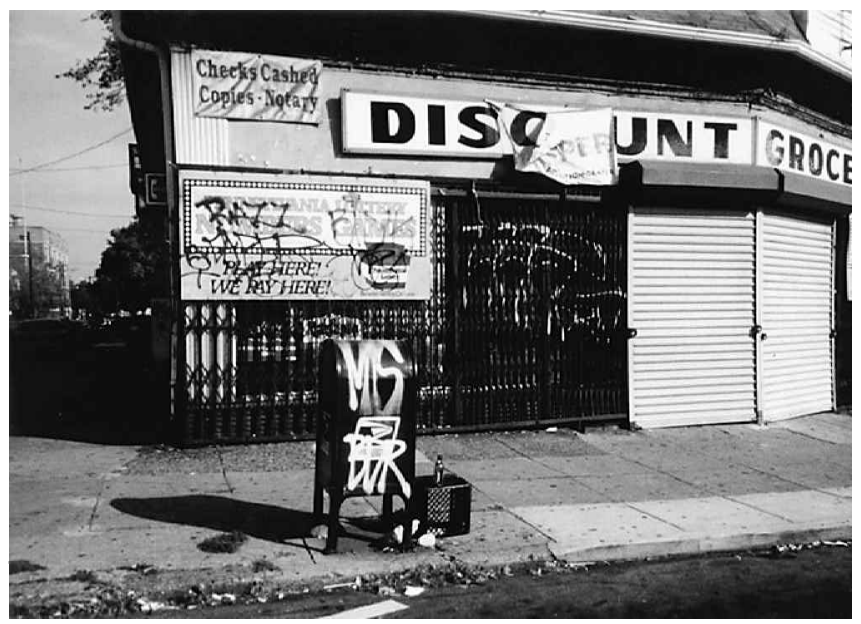

Graffiti covers signs in Kinsessing. Photo by William McKinney.

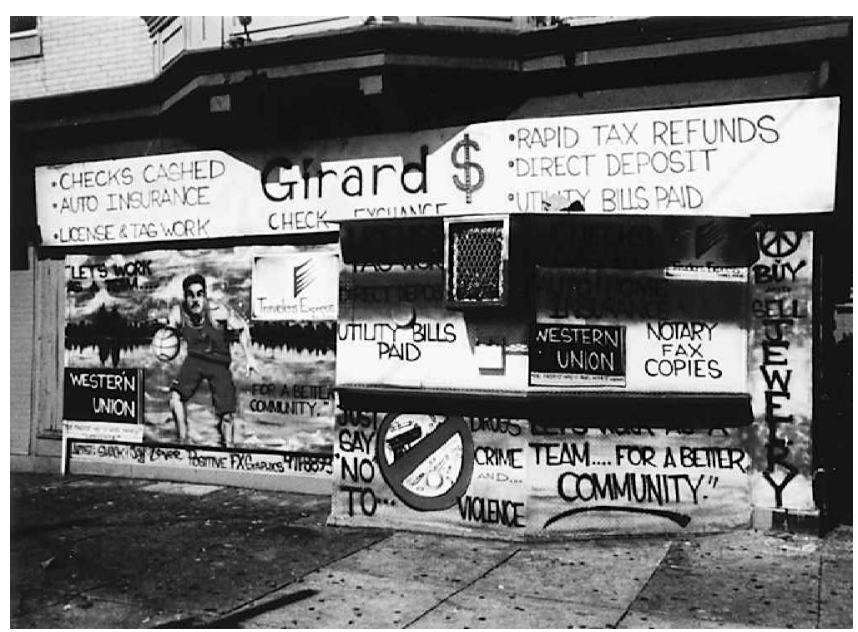

Signs in Kensington. Photo by William McKinney.

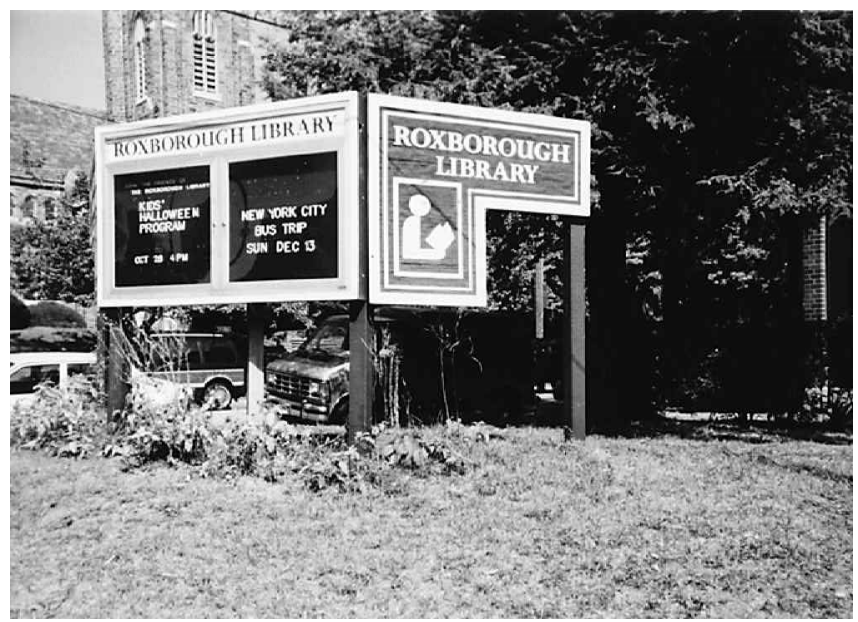

Logographic sign in Roxborough. Photo by William McKinney. 
most prolific in Kensington and Roxborough, suggesting larger business centers than in either of the other neighborhoods. However, the percentage of logographic signs and the condition of signs in both middle-income neighborhoods differed strikingly from those in the two low-income neighborhoods.

Signs in Chestnut Hill and Roxborough were more likely to be logographic and in good readable condition than in the other two neighborhoods. Children could conceivably read their environment through these signs, with pictures, shapes, and colors denoting the library, the bank, and the public telephone. Signs in Kensington and Kingsessing, in contrast, were often graffiti-covered and difficult to decipher. Taggers' distinctive signatures (Lachmann, 1988) would likely make such logos inaccessible to very young children.

Thus once again, we found a wide disparity in opportunity for children to read significant, functional print in their environment. In these middle-income neighborhoods, children had a variety of opportunities to gain an understanding of the purposes and processes of reading, of connecting print with meaningful activity. In the lower income neighborhoods, such opportunities were far more limited and narrow in scope. In these communities, signs were often made inaccessible to children who might pretend to read them.

\section{Public spaces (places) for reading}

Because public places for reading varied by neighborhood and lacked true comparability, the analysis of public spaces focused on qualitative features and the likelihood that these environments might allow for (or even foster) reading opportunities. It was our view that places, and spaces that supported reading activity among adults and peers, provided models of reading as a useful activity. As Table 5 indicates, we visited diners, laundromats, transportation sites, restaurants, and coffee shops, observing features of setting and activities within them.

Table 5 describes the environmental features that appeared to be related to whether or not we would find reading in public spaces. They included such characteristics as comfortable seating, lighting, temperature, attitude of proprietor, and ambiance of setting. In total, 17 features were identified throughout the data across all neighborhood places.

Table 6 uses semantic feature analysis to examine the presence or absence of features in establishments by neighborhood. The analysis once again demonstrated differences between groups. These data indicated that environmental features in the middle-class neighborhoods supported reading activity to a far greater extent than in the lower income neighborhoods. They were more likely to provide the resources, comfort, and ambience that seemed to sustain reading activity.

Two restaurant establishments highlight these contrasts. A popular place to sit for a spell, Taylor's Restaurant is located at a busy intersection in Roxborough. As customers enter, they can grab a newspaper or magazine at one of the two newsstands, located directly outside of the restaurant. Much like a diner, inside the restaurant there are 10 booths and a few smaller tables, as well as padded stools. The stereo is turned to an oldies station.

The mood of the place is comfortable and friendly. Waitresses convey a maternal manner, calling customers "hon" and chatting informally with some. The restaurant has its regulars who are eating a late lunch. Two customers are reading newspapers and are nursing cups of coffee for over an hour. Several used newspapers are folded on a counter next to the coat rack for anybody who wants them. Each waitress takes orders, brings food, and then intrudes only when someone nods for a check or a coffee refill. With the presence of people reading and sitting for long periods of time, little hustle and bustle, and print resources in close proximity, the place appears conducive to reading activity.

Contrast this scenario with the Gold Star Restaurant, located in Kingsessing. Although the place seats almost the same number as Taylor's, the booths are hard and the lighting fluorescent and overly bright. There is only one person eating at the restaurant at the time. But this does not suggest that business is slow. On the contrary, business is bustling, but brisk. Orders are to take out, and booths are mostly for temporary waiting. At one point, three men play video games, killing time until their order is ready, but leave soon after they get their food. The proprietor and employees seem to encourage the quick turnover, looking at hangers-on (us, for example) suspiciously. Others come in, sit at the booth, eat, but do not linger. There are no reading materials available, in or outside the restaurant, and there is no reading activity of any kind.

This pattern would repeat itself in other settings. Overall, environments in low-income neighborhoods were not conducive to reading. Seating was uncomfortable, not sufficient for the number of people who would regularly visit or wait (e.g., at the laundromat, the bus stop); lighting was often glaring; and business owners more often than not were intolerant of hanging about if there was minimal or no financial gain. There were no reading materials and no corroborating activity. Contrary to the sit-down-and-linger activity in Chestnut Hill and Roxborough, there was a take-out and to-go pattern of activity in Kingsessing and Kensington.

Early literacy theorists have posited that children learn about the forms and functions of reading by observ- 
Table 6 Evidence of environmental features in places (spaces) for reading in public

\begin{tabular}{|c|c|c|c|c|}
\hline Environmental features & Kensington & Kingsessing & Roxborough & Chestnut Hill \\
\hline Available seating & 2 & 2 & 5 & 5 \\
\hline Comfortable seating & 1 & 1 & 3 & 3 \\
\hline Availability of reading materials & 1 & 3 & 5 & 5 \\
\hline \multicolumn{5}{|l|}{ Appropriateness of reading } \\
\hline Presence of other readers & 2 & 1 & 4 & 3 \\
\hline Tolerant management & 2 & 3 & 3 & 3 \\
\hline Comfortable temperature & 2 & 4 & 4 & 4 \\
\hline Seasonal weather & 5 & 5 & 5 & 5 \\
\hline Adequate lighting & 5 & 5 & 5 & 5 \\
\hline Nondisruptive noise level & 4 & 5 & 5 & 3 \\
\hline Nondisruptive activity level & 3 & 3 & 5 & 4 \\
\hline Lack of competing activities & 3 & 4 & 4 & 4 \\
\hline Presence of corroborating activities & 2 & 3 & 4 & 4 \\
\hline Good ambience & 0 & 2 & 4 & 4 \\
\hline Friendly staff & 0 & 1 & 3 & 3 \\
\hline Plenty of surrounding space & 2 & 4 & 4 & 5 \\
\hline Cleanliness & 3 & 3 & 5 & 5 \\
\hline Aesthetically pleasing & 3 & 1 & 5 & 5 \\
\hline Total percentage of places & $47 \%$ & $58 \%$ & $91 \%$ & $82 \%$ \\
\hline
\end{tabular}

Note: Total number of features possible in each area $=5$.

criterion score of 5 in each category is used to indicate good quality, with a range of 1 (poor) to 7 (excellent) possible in each category.

Analyses of variance indicated statistically significant differences between groups on both availability and quality of book collections, $F(1,45)=6.32, p<.01 ; F(1,45)$ $=27.46, p<.001$, respectively. Average scores in book availability indicated differences among centers in neighborhoods: Availability was rated as good in middleincome neighborhoods and as adequate in low-income neighborhoods. Differences were even more pronounced for the quality of the book collection: Centers in Chestnut Hill and Roxborough were rated close to excellent (6.9). These centers included attractive displays of books, a variety of genres, and a range of difficulty appropriate to the ages of the children. In Kensington and Kingsessing, however, book areas in child-care centers were rated only somewhat better than adequate (4.5). Book corners were smaller, with a more limited number of books in good condition. Largely subsidized by state funding, center budgets for books had to be shared and used for other basic supplies.

Studies (Morrow \& Weinstein, 1986; Neuman, 1999a) have shown that differences in resources are relat- ed to the amount and time devoted to reading and language-related activities. Therefore, given the increasing number of children who spend the greater portion of their day in child care, such differential access to resources would appear to add yet another factor to the equation of inequality.

School libraries. Our analysis of school libraries indicated a similar but sharper trajectory of inequality. We concentrated on three categories of access: resources, including number and condition of available books and computers; staffing (i.e., librarian's training and years of work experience); and availability (i.e., the number of days the library was open per week). Differences between groups were statistically significant for quality of books, $F$ $(1,26)=6.84, p<.001$, the number of days open, $F(1,26)$ $=3.52, p<.001$; and computer availability, $F(1,26)=3.59$, $p<.001$.

School libraries in low-income neighborhoods were in serious disrepair. As shown in Table 7, the number of books per child was 12.9 for Kensington and 10.6 for Kingsessing; books ranged from poor to good condition. By contrast, collections in school libraries in the middleincome communities ranged from good to excellent condition. There were 18.9 books per child in Roxborough 
Figure 1 Book availability and book quality in preschool classrooms

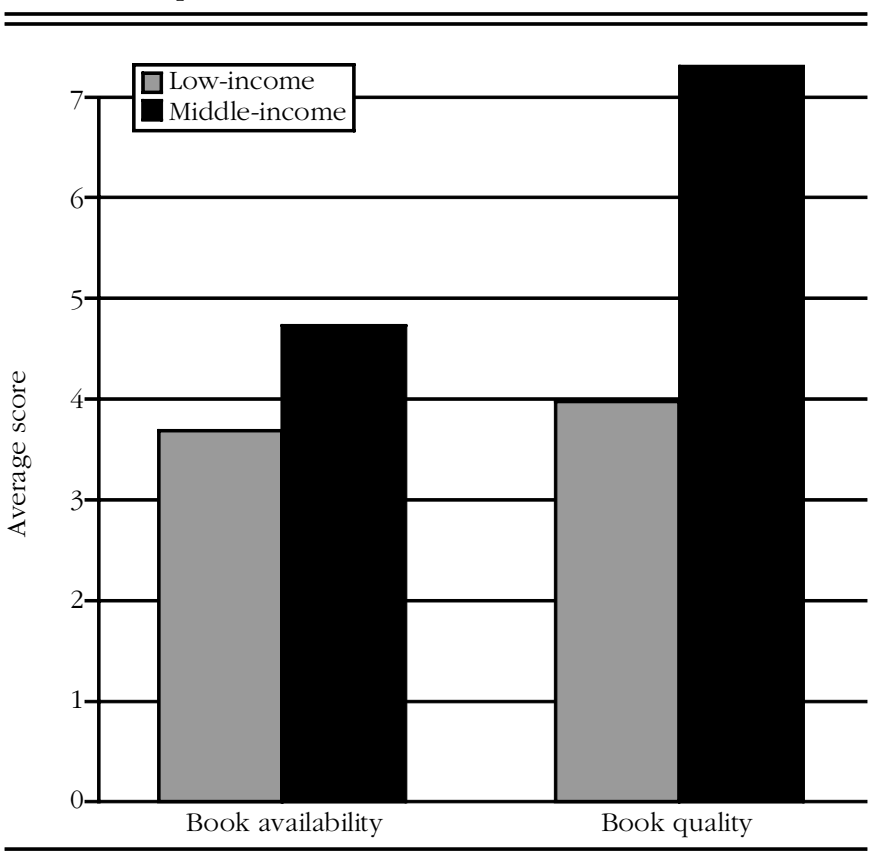

and 25.7 per child in Chestnut Hill. For every computer in the library in the low-income schools, there were three in the middle-income schools. Staffing also varied considerably. There were no trained school librarians available to children in either Kingsessing or Kensington, whereas school librarians had master's degrees and an average of 12 years of school experience in Chestnut Hill and Roxborough neighborhoods. Staffing issues affected the number of library hours or days the library was made available. On average, libraries were open about 3 days a week for children in low-income neighborhoods (ranging from 0 days to 5) compared with 5 days a week in the middle-income neighborhood schools.

Taken together, these data indicated that children who lived in already print-rich environments tended to have school libraries that offered more books, more com- puters for research, better trained librarians with more experience, and more hours to visit during the day.

Unfortunately, those children likely to benefit most from school libraries were offered the poorest services, resources, and access on fewer days of the week.

Public libraries. The final analysis examined local public library branches in each neighborhood. Given its mission and funding sources (i.e., city-wide), here we expected an equal playing field, with resources reflecting both the size and the interests of the population in the catchment area. However, this was not the case. Although certainly not as dramatic as other analyses, Table 8 once again indicated unequal resources. Low-income communities had smaller overall collections, fewer books per child, and more limited nighttime hours than those in the middle-income communities. Children and their parents in Chestnut Hill and Roxborough, on the other hand, were the beneficiaries of more titles, larger book collections, and evening hours, that further extended their access to print resources.

Thus, there were striking differences in the availability of print between middle- and low-income communities at each phase of this ecological analysis. Children from middle-income communities would have access to a large number of print resources, ranging from bookstores, to signs, to observations of people reading in public spaces, to various institutions of learning. Those who came from poorer communities would have to rely on public institutions, whose egalitarian mission was to ensure that books were free to all (Van Slyck, 1995). Yet, even in these public schools and libraries, low-income children would likely be short-changed compared with their counterparts living in higher income neighborhoods. Defining features of class position (e.g., income, social capital) appeared to affect the allocation of print resources not only in private enterprise but in public domains as well.

\section{Discussion}

Environment plays a vital role in children's developing behavior (Bronfenbrenner, 1979; Butterworth, 1993;

Table 7 Condition of school libraries in four neighborhoods

\begin{tabular}{|c|c|c|c|c|c|c|}
\hline Area & Number of books & Books per child & Condition of books & Number of days open & Librarian (degree) & Number of computers \\
\hline Kensington & 7,900 & 12.9 & Poor to good & 3.8 & No trained librarian & 1.4 \\
\hline Kingsessing & 5,400 & 10.6 & Poor to good & 2 & No trained librarian & .5 \\
\hline Roxborough & 8,500 & 18.9 & Good to excellent & 5 & Yes (MS or MLS) & 3.5 \\
\hline Chestnut Hill & 7,700 & 25.65 & Good to excellent & 5 & Yes (MS or MLS) & 4 \\
\hline
\end{tabular}

Note. MS: Master's degree in non-library area. MLS: Master's degree in Library Science. 
Table 8 Description of public library branches in neighborhoods

\begin{tabular}{|c|c|c|c|c|}
\hline Library branch & Kensington & Kinsessing & Roxborough & Chestnut Hill \\
\hline $\begin{array}{l}\text { Size of building } \\
\text { (in square feet) }\end{array}$ & 5,361 & 7,938 & 7,000 & 7,049 \\
\hline $\begin{array}{l}\text { Population served } \\
\text { by branch }\end{array}$ & 14,786 & 35,436 & 36,052 & 10,168 \\
\hline $\begin{array}{l}\text { Population under } \\
14 \text { years of age }\end{array}$ & 4,890 & 9,686 & 6,770 & 1,239 \\
\hline $\begin{array}{l}\text { Size of juvenile } \\
\text { book collection }\end{array}$ & 11,823 & 21,215 & 26,646 & 15,780 \\
\hline Books per child & 2.47 & 2.19 & 3.94 & 12.74 \\
\hline Total book collection & 24,610 & 33,149 & 43,611 & 35,124 \\
\hline Books per adult & 1.66 & .94 & 1.21 & 3.45 \\
\hline \multicolumn{5}{|l|}{ Days and hours open } \\
\hline Monday, Wednesday & 10:00 a.m.-6:00 p.m. & 10:00 a.m.-6:00 p.m. & 12:00 p.m.-8:00 p.m. & 1:00 p.m.-9:00 p.m. \\
\hline Tuesday, Thursday, Friday & 10:00 a.m.-5:00 p.m. & 10:00 a.m. $-5: 00$ p.m. & 10:00 a.m. $-5: 00$ p.m. & 10:00 a.m. $-5: 00$ p.m. \\
\hline Saturday & 1:00 p.m.-5:00 p.m. & 1:00 p.m.-5:00 p.m. & 1:00 p.m.-5:00 p.m. & 1:00 p.m. $-5: 00$ p.m. \\
\hline
\end{tabular}

Note. Data provided from Pennsylvania Branch Public Library Annual Report.

Forman, Minick, \& Stone, 1993). From an ecological perspective, children shape and are shaped by it, engaging in a reciprocal and dynamic relation of mutual accommodation. At its most immediate level (Bronfenbrenner, 1979) (i.e., microsystems), the environment is characterized by the intimacy of interpersonal relations and patterns of activity in face-to-face settings with family and closest relations. At its more distal level, the environment incorporates interconnections between settings (i.e., mesosystems) and external influences in which children do not directly participate but are indirectly affected by them (i.e., exosystems). For example, pervasive poverty, institutional settings like the workplace, and social welfare systems act as indirect environmental influences on children's interactions. They may affect the physical and emotional resources provided to the child (e.g., stress levels due to lack of work), adult responsiveness, and involvement in daily activities (Hart \& Risley, 1995;

McLoyd, 1990). Such indirect influences may exert a powerful influence on the social processes that take place within immediate settings.

Research in early literacy, however, has tended to focus on the immediate setting - the relation of family characteristics, book reading habits, instructional features in the school, and their impact on children's early literacy development-not on the larger contexts, both formal and informal, that may affect events within the immediate set- tings. For example, it is assumed that middle-class parents' book reading habits with young children are a key factor in children's early literacy preparation, and not merely a proxy for all the other events and activities that involve children in literacy in the larger community. Similarly, it is assumed by school districts, as well as society at large, that individual schools in high-socioeconomic status areas produce children who excel in school achievement. But rarely is it recognized that these children generally have higher skills to begin with due to advantages outside school, and not on what the school necessarily provides.

Consequently, we would argue that although immediate interactional contexts may lie at the heart of an explanatory framework for differences in achievement, unexplained variation may stem not just from immediate environments (home, school) but the larger systems that indirectly affect children. As Wilson (1998) described, the immediate context essentially ignores institutionally organized practices and norms that affect social and school outcomes. Included among these are processes of mobility and opportunity, the social isolation in poor neighborhoods and unequal resources that may further extend a community's social isolation, and the privileges and benefits derived from these resources.

This study attempted to examine four community environments, placing print resources specifically under scrutiny. It documented how differences in economic cir- 
cumstances translated into extraordinary differences in the availability of print resources for children who live in lowor middle-income communities. Inequity was reported in the number of resources, choice and quality of materials available, public spaces and places for reading, amount and quality of literacy materials in child-care center resources-even in the public institutions, the schools, and local public libraries in the community. Long before formal schooling begins, considerable variations in patterns of early literacy development are likely to be evident based on the ways in which print is organized in communities.

What might be the consequences of differential access for children's literacy learning? Stanovich and his colleagues (Cunningham \& Stanovich, 1997; Stanovich \& Cunningham, 1992; Stanovich, West, \& Harrison, 1995), for example, have proposed an environmental opportunity hypothesis. Children gain familiarity and practice with exposure to print, creating a reciprocal and increasingly positive relation toward initial and developing reading acquisition. However, those children who lack exposure and experiences with print are less likely to be skilled at the initial acquisition process, less likely to become involved in reading-related activities, and less motivated to read, beginning the spiraling effect of the rich-get-richer, poor-get-poorer phenomenon. Once children are in public schools, the problem often becomes exacerbated through remedial instruction that exposes less skilled children to fewer interactions with text than their more skilled peers (Allington, 1983), providing them ultimately with the very poorest language and literacy instruction. Such unrewarding experiences in reading multiply, with the consequences that children attend less to the comprehensibility of reading, its purpose, and potential usefulness.

Cole and his colleagues (Cole, 1998; Cole, Engestrom, \& Vasquez, 1997), however, cautioned that it is not only familiarity of materials and practice opportunities that must be considered in comparing children's developing skills. From an activity perspective, involvement in activities fosters socially constructed modes of thinking. For example, Rogoff (1982), in a study of Western and non-Western cultures, reported that children who were less familiar with formal schooling experienced difficulty not in everyday memory problems, but in listmemory tasks, considered to be a more school-related activity. Book-related experiences, therefore, may be intimately related to the cognitive activities usual for children, such as the use of decontextualized language, demonstrating how basic mental processes and activities become integrated through experience.

Therefore, given differential access to reading and writing materials early in life, some children are likely to come to school better prepared for the ways of learning and thinking that are nurtured in school; others might de- velop problem-solving skills that are either unacknowledged or run counter to school learning. Such differences have important implications for literacy development, suggesting a number of important accommodations for improving children's achievement.

One type of accommodation involves redesigning classrooms to ensure better access to literacy. There is an accumulated body of research (Morrow \& Weinstein, 1986; Neuman, 1996; Neuman \& Roskos, 1997) that has demonstrated the effects of environmental design features on the frequency and complexity of children's uses of literacy materials (e.g., books, print-related props). Emphasizing the importance of physical and psychological proximity of literacy resources, recent studies (Neuman, 1999a; Neuman \& Celano, in press) provided powerful evidence that quality classroom libraries in close proximity to children, and child-care workers trained to develop the psychological resources (i.e., instructional support of language and literacy), could greatly improve children's beginning literacy skills. Similarly, research by Elley (1996) has demonstrated the benefits of greater access to resources for primary-age children on vocabulary and skill development in countries around the world.

Changes in designs of classrooms are needed and important; however, they cannot begin to bridge the gulf between school learning and the more informal learning that occurs in daily activity. A second and more dramatic accommodation is to broaden our definition of literacy from one that is school bound to one that is more situation based. Strategies for learning about literacy need to be tied to real, authentic activity that is better connected to the more context-based problems and techniques of practical life. A better balance between decontextualized learning and functional activity might take advantage of what children bring to the school setting, focusing on a wider range of capabilities rather than perceived incapacities and deficiencies. Much of the work on literacy and play (Neuman \& Roskos, 1997), for example, has been to create contexts that engage young children in problemsolving activity, reflecting the types of purposes, uses of literacy, and scripts and routines in everyday life.

Most important, a third accommodation is necessary and related to inherent limitations in this study. This study acknowledged differences in communities but did not examine the genesis of these differences, including such issues as power, authority, and cultural capital (Bourdieu, 1977). Thus, in focusing on the resources considered to influence school literacy success, we did not highlight the specialized funds of knowledge that low-income children bring to early childhood and school settings. In this respect, we perhaps unfairly privileged school-based learning in contrast to the learning experiences and ways of thinking that are nurtured in daily activities and homes of 
the specific communities in which these children lived. Yet, as a number of scholars have documented (Au, 1998; Taylor \& Dorsey-Gaines, 1988), although many families in poverty may value literacy, they have only minimal connections with schools. Clearly, we need to strengthen these connections and build upon community assets if literacy is to be a cultural, social, and cognitive achievement for all children.

Finally, there is advocacy work to do here. Literacy scholars and advocates must work in collaboration with policy makers to ensure more equitable funding of resources for children in child care, school libraries, and public libraries. School district funds must be dedicated (e.g., in contrast to discretionary funds) to build good libraries for children and their families who may use them as well (e.g., Library Power Schools, Neuman, 1999b). Further, we must begin to calibrate school and public library activity (and thus, the allocation of resources) differently to account for in-building uses. Circulation figures, the most prevalent metric to date, have been shown to underestimate library use among low-income families who can ill-afford late fee charges. And finally, educators must begin to stake out strong position statements in collaboration with other organizations to promote greater equity. The International Reading Association's recent position statement (2000) arguing for classroom libraries that ensure at least seven high-quality books per child begins to address this important issue.

\section{REFERENCES}

ALLINGTON, R. (1983). The reading instruction provided readers of differing reading abilities. Elementary School Journal, 83, 548-559.

ANDERSON-YOCKEL, J., \& HAYNES, W. (1994). Joint book-reading strategies in working-class African American and white mother-toddler dyads. Journal of Speech and Hearing Research, 37, 583-593.

$\mathrm{AU}, \mathrm{K}$. (1998). Social constructivism and the school literacy learning of students of diverse backgrounds. Journal of Literacy Research, 30, 297-317.

BOURDIEU, P. (1977). Cultural reproduction and social reproduction. In J. Karabel \& A. H. Halsey (Eds.), Power and ideology in education (pp. 487-511). New York: Oxford.

BRONFENBRENNER, U. (1979). The ecology of human development. Cambridge, MA: Harvard University Press.

BUTTERWORTH, G. (1993). Contexts and cognition in models of cognitive growth. In P. Light \& G. Butterworth, Contexts and cognition: Ways of learning and knowing (pp. 1-13). Hillsdale, NJ: Erlbaum.

CHILDREN'S DEFENSE FUND. (1999). The state of American's children yearbook 1999. Washington, DC: Author.

COLE, M. (1998). Cultural psychology. Cambridge, MA: Belknap.

COLE, M., ENGESTROM, Y., \& VASQUEZ, O. (Eds.). (1997). Mind, culture and activity. New York: Cambridge University Press.

CONNELL, J.P., KUBISCH, A., SCHORR, L., \& WEISS, C. (Eds.). (1995). New approaches to evaluating community initiatives. Washington, DC: Aspen Institute.

CUNNINGHAM, A.E., \& STANOVICH, K. (1997). Early reading acquisition and its relation to reading experience and ability 10 years later. Developmental Psychology, 33, 934-945.

DONAHUE, P., VOELKL, K., CAMPBELL, J., \& MAZZEO, J. (1999). NAEP 1998 reading report card for the nation. Washington, DC: Office of Educational Research and Improvement.

ELLEY, W. (1996). Lifting literacy levels in developing countries: Some implications from IEA studies. In V. Greaney (Ed.), Promoting reading in develop- ing countries (pp. 39-53). Newark, DE: International Reading Association. ENTWISTLE, D., ALEXANDER, K., \& OLSON, L.S. (1997). Children, schools, and inequality. Boulder, CO: Westview.

FORMAN, E., MINICK, N., \& STONE, C.A. (Eds.). (1993). Contexts for learning. New York: Oxford University Press.

GALLIMORE, R., \& GOLDENBERG, C. (1993). Activity settings of early literacy: Home and school factors in children's emergent literacy. In E. Forman, N. Minick, \& C.A. Stone (Eds.), Contexts for learning (pp. 315-335). New York: Oxford University Press.

GIBSON, E. (1979). The ecological approach to visual perception. Boston: Houghton Mifflin.

GOODMAN, Y. (1986). Children coming to know literacy. In W. Teale \& E. Sulzby (Eds.), Emergent literacy (pp. 1-14). Norwood, NJ: Ablex.

GREENFIELD, P.M. (1974). Comparing dimensional categorization in natural and artificial contexts: A developmental study among the Zinacantecos of Mexico. Journal of Social Psychology, 93, 157-171.

HARMS, T., \& CLIFFORD, R. (1980). The early childhood environmental rating scale. New York: Teachers College Press.

HART, B., \& RISLEY, T. (1995). Meaningful differences. Baltimore: Brookes. INTERNATIONAL READING ASSOCIATION. (2000). Providing books and other print materials for classroom and school libraries: A position statement. Newark, DE: Author.

JENCKS, C. (1973). Inequality. Cambridge, MA: Harvard University Press. JENCKS, C., \& PETERSON, P. (Eds.). (1991). The urban underclass. Washington, DC: The Brookings Institute.

JENCKS, C., \& PHILLIPS, M. (Eds.). (1998). The black-white test score gap. Washington, DC: The Brookings Institute.

JUEL, C., GRIFFITH, P.L., \& GOUGH, P. (1986). Acquisition of literacy: A longitudinal study of children in first and second grade. Journal of Educational Psychology, 78, 243-255.

KRASHEN, S. (1995). School libraries, public libraries, and the NAEP reading scores. School Library Media Quarterly, 24, 235-237.

KRASHEN, S. (1998). Bridging inequity with books. Educational

Leadership, 54, 18-22.

LACHMANN, R. (1988). Graffiti as career and ideology. American Journal of Sociology, 94, 229-250.

LAREAU, A. (1989). Home advantage: Social class and parental intervention in elementary education. New York: Falmer Press.

LAVE, J. (1980). What's special about experiments as contexts for thinking The Quarterly Newsletter of the Institute for Comparative Human Development, 4, 86-91.

MACLEOD, J. (1995). Ain't no makin' it. Boulder, CO: Westview Press. MADDEN, N.A., SLAVIN, R., KARWEIT, N., DOLAN, L., \& WASIK, B. (1993). Success for All: Longitudinal effects of a restructuring program for innercity elementary schools. American Educational Research Journal, 30, 123-148.

MANDLER, J., SCRIBNER, S., COLE, M., \& DEFOREST, M. (1980). Crosscultural invariance in story recall. Child Development, 51, 19-26.

MCGEE, L., LOMAX, R., \& HEAD, M. (1988). Young children's written language knowledge: What environmental and functional print reading reveals. Journal of Reading Behavior, 20, 99-118.

MCGILL-FRANZEN, A., \& ALLINGTON, R. (1997, April). Print-rich kindergarten classrooms dramatically enhance learning. Paper presented at the American Educational Research Association, Chicago.

MCLOYD, V. (1990). The impact of economic hardship on black families and children: Psychological distress, parenting, and socioemotional development. Child Development, 61, 311-346.

MCQUILLAN, J. (1998). The literacy crisis. Portsmouth, NH: Heinemann. MOLL, L., \& GREENBERG, J. (1990). Creating zones of possibilities: Combining social contexts for instruction. In L. Moll (Ed.), Vygotsky and education (pp. 319-348). New York: Cambridge University Press.

MORROW, L.M., \& WEINSTEIN, C. (1986). Encouraging voluntary reading: The impact of a literature program on children's use of library centers. Reading Research Quarterly, 21, 330-346.

NATRIELLO, G., MCDILL, E., \& PALLAS, A. (1990). Schooling disadvantaged children. New York: Teachers College Press.

NEUMAN, S.B. (1995). Enhancing adolescent mothers' guided participation in literacy. In L.M. Morrow (Ed.), Family literacy (pp. 104-114). Newark, DE: International Reading Association.

NEUMAN, S.B. (1996). Children engaging in storybook reading: The influence of access to print resources, opportunity, and parental interaction. Early 
Childhood Research Quarterly, 11, 495-514.

NEUMAN, S.B. (1999a). Books make a difference: A study of access to literacy. Reading Research Quarterly, 34, 286-311.

NEUMAN, S.B. (1999b). Findings from the evaluation of the National Library

Power Program. Washington, DC: DeWitt Wallace-Reader's Digest Fund.

NEUMAN, S.B., \& CELANO, D. (in press). Books Aloud: A campaign to "put

books in children's hands." The Reading Teacher.

NEUMAN, S.B., \& ROSKOS, K. (1997). Literacy knowledge in practice:

Contexts of participation for young writers and readers. Reading Research

Quarterly, 32, 10-32.

NINIO, A. (1980). Picturebook reading in mother-infant dyads belonging to

two subgroups in Israel. Child Development, 51, 587-590.

PELLEGRINI, A.D., GALDA, L., JONES, I., \& PERLMUTTER, J. (1995).

Joint reading between mothers and their Head Start children: Vocabulary devel-

opment in two text formats. Discourse Processes, 19, 441-463.

PETERSON, P. (1991). The urban underclass and the poverty paradox. In

C. Jencks \& P. Peterson (Eds.), The urban underclass (pp. 3-27). Washington,

DC: The Brookings Institute.

ROGOFF, B. (1982). Integrating context and cognitive development. In M.E.

Lamb \& A.L. Brown (Eds.), Advances in developmental psychology (pp. 125-169).

Hillsdale, NJ: Erlbaum.

ROGOFF, B. (1990). Apprenticeship in thinking. New York: Oxford

University Press.

ROGOFF, B., MOSIER, C., MISTRY, J., \& GONCU, A. (1993). Toddlers'

guided participation with their caregivers in cultural activity. In E. Forman, N.

Minick, \& A. Stone (Eds.), Contexts for learning: Sociocultural dynamics in chil-

dren's development (pp. 230-253). New York: Oxford University Press.

SCRIBNER, S., \& COLE, M. (1981). The psychology of literacy. Cambridge,

MA: Harvard University Press.

SIGEL, I. (1982). The relationship between parental distancing strategies and the child's cognitive behaviour. In L. Laosa \& I. Sigel (Eds.), Families as learning environments for children (pp. 47-86). New York: Plenum.

SINNOTT, J.D. (1975). Everyday thinking and Piagetian operativity in adults. Human Development, 18, 430-443.

SMITH, C., CONSTANTINO, B., \& KRASHEN, S. (1996). Differences in print environment for children in Beverly Hills, Compton, and Watts. Emergency Librarian, 24(4), 8-10.

SNOW, C., BURNS, M.S., \& GRIFFIN, P. (1998). Preventing reading difficulties in young children. Washington, DC: National Academy Press.

SONNENSCHEIN, S., BRODY, G., \& MUNSTERMAN, K. (1996). The influ- ence of family beliefs and practices on children's early reading development. In L. Baker, P. Afflerbach, \& D. Reinking (Eds.), Developing engaged readers in school and home communities (pp. 1-20). Mahwah, NJ: Erlbaum.

STAHL, S., \& MURRAY, B. (1993). Environmental print, phonemic awareness, letter recognition, and word recognition. In D. Leu \& C. Kinzer (Eds.), Examining central issues in literacy research, theory, and practice: 42nd yearbook of the National Reading Conference (pp. 227-233). Chicago: National Reading Conference.

STANOVICH, K., \& CUNNINGHAM, A. (1992). Studying the consequences of literacy within a literate society: The cognitive correlates of print exposure. Memory \& Cognition, 20(1), 51-68.

STANOVICH, K., \& CUNNINGHAM, A. (1993). Where does knowledge come from? Specific associations between print exposure and information acquisition. Journal of Educational Psychology, 85, 211-229.

STANOVICH, K.E., \& WEST, R. F. (1989). Exposure to print and orthographic processing. Reading Research Quarterly, 24, 402-433.

STANOVICH, K., WEST, R., \& HARRISON, M. (1995). Knowledge growth and maintenance across the life span: The role of print exposure. Journal of Educational Psychology, 31, 811-826.

TAYLOR, D., \& DORSEY-GAINES, C. (1988). Growing up literate: Learning from inner-city families. Portsmouth, $\mathrm{NH}$ : Heinemann.

TEALE, W.H. (1986). Home background and young children's literacy development. In W. H. Teale \& E. Sulzby (Eds.), Emergent literacy (pp. 173-206). Norwood, NJ: Ablex.

TEALE, W.H., \& SULZBY, E. (1989). Emergent literacy: New perspectives. In D. Strickland \& L. M. Morrow (Eds.), Emerging literacy: Young children learn to read and write (pp. 1-15). Newark, DE: International Reading Association.

THARP, R., \& GALLIMORE, R. (1988). Rousing minds to life. New York: Cambridge University Press.

VAN SLYCK, A. (1995). Free to all. Chicago: University of Chicago Press.

WILSON, W.J. (1987). The truly disadvantaged. Chicago: University of Chicago Press.

WILSON, W.J. (1997). When work disappears: The world of the new urban poor. New York: Knopf

WILSON, W.J. (1998). The role of the environment in the black-white test score gap. In C. Jencks \& M. Phillips (Eds.), The black-white test score gap (pp. 501-510). Washington, DC: The Brookings Institute.

Received January 25, 2000

Final revision received June 8,2000 Accepted July 8, 2000 